\title{
Relation Of Gender In Supporting Food Security Movement Program Through The Use of Backyard Land At Households Level (Case Study)
}

\section{Zulfadriani Hamzah¹, Sitti Bulkis 2, Novaty Eny Dungga ${ }^{3}$, Mardiana E Fachry4, Nursini ${ }^{5}$, Hasniati6, Sitti Nurani Sirajuddin ${ }^{7}$}

${ }^{1}$ Hasanuddin University, Student of Gender and Development Study Program, Postgraduate School, Makassar. Indonesia.

${ }^{2}$ Hasanuddin University, Lecturers of Gender and Development Study Program, Postgraduate School, Makassar. Indonesia.

${ }^{3}$ Hasanuddin University, Lecturers of Gender and Development Study Program, Postgraduate School, Makassar. Indonesia

${ }^{4}$ Hasanuddin University, Lecturers of Gender and Development Study Program, Postgraduate School, Makassar. Indonesia.

${ }^{5}$ Hasanuddin University, Lecturers of Gender and Development Study Program, Postgraduate School, Makassar. Indonesia.

${ }^{6}$ Hasanuddin University, Lecturers of Gender and Development Study Program, Postgraduate School, Makassar. Indonesia.

${ }^{7}$ Hasanuddin University, Lecturers of the Agribusiness Departement, Graduate Studies Program. Makassar, Indonesia.

Correspondence Author: Zulfadriani Hamzah. Hasanuddin University, Students of Gender and Development Study Program, Postgraduate School. 90245, Makassar, Indonesia.

E-mail: zulfadrianiulfa@yahoo.com

Received date: 9 December 2019, Accepted date: 21 January 2020, Online date: 31 January 2020

Copyright: (c) 2020 Zulfadriani Hamzah et al., This is an open-access article distributed under the terms of the Creative Commons Attribution License, which permits unrestricted use, distribution, and reproduction in any medium, provided the original author and source are credited.

\begin{abstract}
The utilization of yard is a family farm which involves all household members so that there is a gender relation in its implementation. This study aims to analyze gender relations on yard utilization program. This research was carried out in Poleonro Village, Lamuru District, Bone Regency. Respondents in this study were 81 households chosen based on the number given. Data analysis method used was quantitative descriptive with Moser gender analysis. The results showed that (1) Gender relations were based on time allocation for productive activities both in the agricultural sector (purchase of inputs, determination of commodities, distributing of products and utilization of results) and non-agricultural sector was mostly done by men. Whereas, reproductive activities (menu planning, food processing and serving, children's education, family health and clean the house) were mostly done by wives as housewives meant the husband did more productive activities and the wife did more reproductive activities. The total time allocation used by the husband is $\mathbf{1 1 . 9 2}$ hours/day and the wife $\mathbf{1 2 . 9 4}$ hours/day both husband and wife still had enough free time so they could be actively involved in the use of the yard (2) Based on the decision making, there was a less equal decision making because decision making of the husband himself was still quite high in productive activities and his own wife in reproductive activities, especially related to household food. The husband also decided to participate in the socialization of empowerment activities, although in this case empowerment was aimed at all household members, especially wives who did more domestic works.
\end{abstract}

Keywords: Gender, Food Security, Backyard, Households.

\section{INTRODUCTION}

Food is one of the most basic needs of humans. Food that is safe for consumption is available in sufficient quantity and quality and is distributed with prices that can be reached by the community to support daily activities is something that must be met to realize food security [1]. If approved on the second objective of Sustainable Development Goals (SDGs), namely approval, food welfare is one of the targets that must be agreed to be accompanied by improved nutrition and sustainable agriculture. Safe and nutritious food throughout the year is the focus of these two SDGs.

Based on the Food Security and Vulnerability Atlas (FSVA) in 2018, there are 81 food-insecure districts out of a total of 416 districts in Indonesia. One of the main indicators causing vulnerability to food insecurity in that area is the high number of households with a share of food expenditure $>65 \%$ of total expenditure [2].

Efforts that can be made in reducing expenditure on food and providing enough food for families maximize the utilization of resources owned by households, which is land resources namely home yard. By producing food independently, households will 
more easily obtain a variety and safe foods for families. To overcome the problem of food insecurity at the individual, household and community levels is the availability of food diversity [3].

The problem in using a plot of land is the knowledge of human resources, in this case, household members related to planting patterns, technology, especially regarding the benefits of the plot of land to the pattern of food consumption that is recommended to meet daily nutritional needs so that it tends to leave the yard unused. One of the efforts made by the government to overcome these problems is to formulate an empowerment program to educate the community so that they can utilize their land well.

In South Sulawesi, there was an increase in the quality of population food consumption from 2016 to 2017 based on the Hope Food Pattern (PHP), namely $80.5 \%$ to $92.6 \%$. Even so, food consumption is still heavily dominated by grains, especially rice, which is $114.7 \mathrm{~kg} / \mathrm{cap} /$ year [4]. Therefore, the use of home yard that can support household food diversity needs to be done so that food consumption patterns are more diverse so that nutritional needs can be met.

The home yard can be an additional source of food that can be managed together by household family members. So far, the yard is considered as the domestic domain because the majority of the orientation is only for consumption, reached the commercial direction yet, so that the yard is always related to women or housewives. Based on the description above, the writer is interested in researching "Relation Of Gender in Supporting Food Security Movement Program Through The Use Of Backyard Land At Households Level".

\section{METHODOLOGY}

This research was carried out in Poleonro Village, Lamuru District, Bone Regency. Determination of this location is done on purpose (purposive) by considering that in the research location, there is a plot of land use program and the location is the best village in the climate village program (Proklim). This study was conducted in September 2019.

Determination of respondents based on the number of households in the study area as many as 418 households. The Slovin formula for determining the minimum respondent size (n) in the study area is known the number of households (N) at the significance level $(\alpha)$ of $10 \%$ is as follows:

$n=\frac{N}{1+N \alpha^{2}}$

$n=\frac{418}{1+418(0,1)^{2}}$

$n=\frac{418}{5,18}$

$n=80,6$

Based on the formula above, the number of respondents in the study area is 81 households which will then be chosen based on the number given. This sampling technique is called the systematic sampling technique that is a sampling technique based on the order of the population that has been numbered. The community is 418 households and a sample of 81 households so that the interval for each numbering is 5 households.

The analytical tool used in Moser is triple roles, as follows:

a. Productive roles are the roles of men and women in activities related to goods and services.

b. The reproductive role is the role of men and women in activities related to household care.

c. The social role is the role of men and women in participation in community activities such as salvation and mutual assistance

\section{RESULTS AND DISCUSSION}

In this study, gender relations in the three gender roles, namely productive, reproductive and social functions in the household, can be seen based on the time allocation spent by each household member and decision making on the gender role.

\section{Time Allocation}

The time allocation in question is the time allocated by each household member in each activity, both domestic and public area.

The time allocation for the Poleonro Village community households namely:

Table 1: Average distribution of time (hours/day) for households in Poleonro Village, 2019

\begin{tabular}{|c|c|c|c|c|c|}
\hline \multirow{3}{*}{ No } & \multirow{3}{*}{ Gender Role Activity } & \multicolumn{4}{|c|}{ Time Allocation } \\
\hline & & \multirow{2}{*}{ Husband } & \multirow{2}{*}{ Wife } & \multicolumn{2}{|c|}{ Other Family Member } \\
\hline & & & & Male & Female \\
\hline 1 & Productive & 6,50 & 1,99 & 1,00 & 1,00 \\
\hline
\end{tabular}




\begin{tabular}{|l|l|c|c|c|c|}
\hline 2 & Reproductive & 1,86 & 8,34 & 0,30 & 0,75 \\
\hline 3 & Other activity & 3,56 & 2,61 & 0,24 & 0,25 \\
\hline \multicolumn{2}{|l|}{ Total } & 11,92 & 12.94 & 1,54 & 2,00 \\
\hline
\end{tabular}

Source: Primary Data after processing, 2019

Table 1 shows that men mostly do the average time allocation for productive activities both in the agricultural sector (purchase of inputs, determination of commodities, distribution of products and utilization of results) and the non-agricultural sector. Whereas, wives mostly do creative activities (menu planning, food processing and serving, children's education, family health and clean the house) as housewives. Although more time is allocated to productive activities, the husband also participates in some reproductive activities and also wife participates in reproductive activities. Besides that, the husband and wife also allocate their time to social movements. Nevertheless, time allocated by the wife on a day is more than the husband which is 12.94 hours per day. This is due to the amount of time has allocated in reproductive activities by the wife.

The female respondents in this study assume that this is naturally reasonable because domestic matters are the responsibility of the wife, while the husband has the responsibility to earn a living. Such an assumption is a culture that is inherent in society both in developing and developed countries. The results of several studies conducted in developed countries show that domestic work is the responsibility of women, and it happens consistently [5].

Gender relations in the household both in productive, reproductive and social activities make household members able to engage in certain activities even though in relatively less time there are even activities that are carried out together. In social activities, especially the manufacture of organic fertilizer which will be applied to the yard, female household members, or wives who are more involved. During the socialization process, direct training was also conducted so that the community could understand the manufacturing process well. This is in accordance with the results of research that participatory training through practice or experimentation gives satisfaction to farmers because it can be applied directly to motivate farmers to improve their economy [6].

From the description above it can be seen that the gender relations in the respondent's household in productive, reproductive and social activities based on time allocation ie the total time allocation used by the husband is 11.92 hours/day and wife 12.94 hours/day. This is because the wife allocates more time to reproductive activities besides doing productive activities so that based on the total allocation of time spent, the husband has more free time than the wife. Both husband and wife carry out productive and reproductive activities to meet the basic needs of the household namely food. The involvement of the wife in productive activities can contribute to the household, besides it can increase economic empowerment to the wife or housewife [7]. By utilizing the plot of land, the wife can reduce household expenses, especially for the fulfillment of food.

The wife allocates more time in reproductive activities, especially in terms of food processing and provision. The involvement of the wife in empowerment activities will provide benefits to household health, especially if the material obtained can be applied in the household. Reproductive work is very closely related to homework so that to do the land use activities of the wife's yard has an opportunity other than the time side; also the location of the yard close to home makes it possible for the wife to carry out activities easily. Society, in this case farmers has a positive response to the application of technology if the making and how to apply it is not difficult [8]. Therefore, the use of the yard can be done together by husband and wife so that the results obtained will be maximized. Utilization of the plot of land does not only provide benefits to meet the nutritional needs of the family but also has an impact on environmental sustainability and sustainable agriculture.

\section{Decision Making}

Decision making is the process of choosing or determining the possibilities of an uncertain situation [9]. In a household, decision making is a process of mutual influence between household members and the choices made.

The household decision making at Poleonro Village is as follows:

Table 2: Poleonro Village Community Household Decision Making, 2019

\begin{tabular}{|c|c|c|c|c|c|c|}
\hline \multirow{2}{*}{ No } & \multirow{2}{*}{ Gender Role Activity } & \multicolumn{5}{|c|}{ Decision Making } \\
\hline & & 1 & 2 & 3 & 4 & 5 \\
\hline 1 & $\begin{array}{cc} & \text { Productive } \\
- & \text { Purchasing of saprodi } \\
- & \text { Commodity determination } \\
& -\quad \text { Distribution } \\
- & \text { Utilization of community }\end{array}$ & $\begin{array}{l}98,7 \\
98,7 \\
59,3 \\
74,0\end{array}$ & $\begin{array}{c}0 \\
12,3 \\
20,9 \\
13,3\end{array}$ & $\begin{array}{c}1,23 \\
1,23 \\
11,1 \\
4,9\end{array}$ & $\begin{array}{c}0 \\
17,3 \\
0 \\
6,67\end{array}$ & $\begin{array}{c}0 \\
6,67 \\
0 \\
6.67\end{array}$ \\
\hline 2 & $\begin{array}{cc} & \text { Reproductive } \\
- & \text { Menu planning } \\
- & \text { Processing and serving } \\
- & \text { Children's education } \\
- & \text { Household expenditure } \\
& -\quad \text { Family Health } \\
- & \text { Cleaning the house }\end{array}$ & $\begin{array}{l}0 \\
0 \\
0 \\
0 \\
0 \\
0\end{array}$ & $\begin{array}{l}0 \\
0 \\
0 \\
0 \\
0 \\
0\end{array}$ & $\begin{array}{c}1,2 \\
16 \\
23,5 \\
23,5 \\
18,5 \\
1,23\end{array}$ & $\begin{array}{c}22.2 \\
35,8 \\
46,9 \\
30,9 \\
44,4 \\
0\end{array}$ & $\begin{array}{l}76.5 \\
48,5 \\
29,6 \\
45,7 \\
37,0 \\
98,7\end{array}$ \\
\hline
\end{tabular}




\begin{tabular}{|c|c|c|c|c|c|c|}
\hline 3 & $\begin{array}{cc}\text { Other Activity } \\
-\quad \text { Thanksgiving } \\
-\quad \text { Mutual cooperation } \\
-\quad \text { Following counseling } \\
\text { Agriculture } \\
\text { - Attend the empowerment } \\
\text { program socialization }\end{array}$ & $\begin{array}{c}0 \\
19,7 \\
72,8 \\
49,4\end{array}$ & $\begin{array}{c}0 \\
20,9 \\
13,6 \\
14,8\end{array}$ & $\begin{array}{c}24,7 \\
19,7 \\
1,23 \\
\\
7,4\end{array}$ & $\begin{array}{l}23,6 \\
19,7 \\
1,23 \\
\\
12,3\end{array}$ & $\begin{array}{c}51,9 \\
19,7 \\
0 \\
16\end{array}$ \\
\hline
\end{tabular}

Table 2 shows that in productive activities, the decision making is mostly done by the husband himself with a percentage of input production $(98.7 \%)$, commodity determination $(98.7 \%)$, sales of results $(59.3 \%)$. While the wife herself makes more decisions in almost all reproductive activities, namely menu planning (76.5\%), processing and serving (48.5\%), household expenditure $(45.7 \%)$ and cleaning the house $(98.7 \%)$. The decision making for children's education and family health is mostly done by the wife. In social community activities, the husband makes more decisions related to participating in counseling activities $(72.8 \%)$ and participating in the empowerment program socialization (49.4\%), in cooperation activities, collective decision-making is carried out but mostly decided by the husband. Whereas the wife makes more decisions related to salvation or attending family events. In contrast to the results of research on the Kashmir community that women are not given the opportunity to spend their own income in the household even to make decisions about the use of the money [10], in the Poleonro Village community decision-making regarding reproductive activities, one of them spending on housing needs ladders are mostly done by wives or women.

Based on the percentage above, it can be seen the level of equality in community household decision making. Equality is divided into three, namely unequal if the decision making is mostly done by the husband alone or his own wife, less equal if done together but the wife or husband remains more numerous and equal if the decision making is carried out together. The gender relations in decision making in community households in Poleonro Village are as follows:

Table 3: Gender Relations in Decision Making in Households in Poleonro Village, 2019.

\begin{tabular}{|c|c|c|c|}
\hline No. & Equality evel & Amount (n) & Percentage (\%) \\
\hline 1 & Equal & 1 & 1,20 \\
\hline 2 & Less Equal & 43 & 53,10 \\
\hline 3 & Not Equal & 37 & 45,70 \\
\hline \multicolumn{2}{|c|}{ Total } & 81 & 100 \\
\hline
\end{tabular}

Source: Primary Data after processing, 2019

Table 3 shows that gender relations related to decision making are less equal. This is due to the husband's own decision making is still quite high in productive activities and his own wife in reproductive activities, especially related to household food. The results of this study are consistent with research that decision making in food matters tends to be taken by wives [11]. It can be concluded that decision making like this still very entrenched in the community. If you look back at the time allocation, the husband also performs reproductive activities and the wife participates in productive activities so it would be better if the decision making more done together.

In gender relations based on decision making, as many as $53.10 \%$ of the number of respondents households were less equal in making decisions. Decision making is closely related to time allocation. The husband makes more of his own decisions on productive activities, as well as his wife makes more of his own decisions on reproductive activities, especially those related to the food supply. The food provided by the wife is for the husband and other household members, so food hygiene and health are important things that must be considered. Therefore, the Poleonro Village Government, through the Healthy Village Working Group strongly recommends the use of the yard area. The husband also decided to participate in the socialization of empowerment activities, although in this case empowerment was aimed at all household members, especially wives who did more domestic work.

\section{CONCLUSIONS AND RECOMMENDATIONS}

In Poleonro Village household gender relations are seen based on time allocation, and decision making on productive, reproductive and social activities. Gender relations are based on time allocation, meaning that the husband does more productive activities and the wife does more reproductive activities. Both husband and wife still have enough free time so they can be actively involved in the use of the yard. Based on decision making, there is a less equal decision making because the husband makes more decisions on productive activities and the wife makes more decisions on reproductive activities. Therefore, the empowerment program pays attention to gender relations in the household so that the community can actively participate in the programs that are prepared. 
[1] Saliem H P, MAriani Y, Marisa T B and Purwantini. Analisis Kerawanan Pangan Wilayah dalam Perspektif Desentralisasi Pembangunan. Bogor; 2016.

[2] Badan Ketahanan Pangan Kementerian Pertanian. Peta Ketahanan dan Kerentanan Pangan [internet]. 2018. [cited 12 April 2019]. Available from : bkp.pertanian.go.id. peta-ketahanan-dan-kerentanan-pangan

[3] Agus A, Anggoro U K, Machfoedz M M, Darwanto D H, Radhi F, Sasono A, et al. Jihad menegakkan kedaulatan pangan: suara dari Bulaksumur. Yogyakarta. Gadjah Mada University Press; 2014.

[4] Badan Ketahanan Pangan Kementerian Pertanian. Direktori Perkembangan Konsumsi Pangan [internet]. 2018. [cited 15 April 2019]. Available from : bkp.pertanian.go.id.

[5] Taridala S A A and Darwis. Alokasi Waktu Gender, Sumber Pendapatan dan Ketahanan Pangan Rumah Tangga di Daerah Rawan Pangan. Seminar Nasional : Kedaulatan Pangan dan Energi. Madura. 2012.

[6] Rasyid T G, Hasan S, Rasjid S and Sirajuddin S, N. Development model of goat farming business base on productive economy in Majene regency, West Sulawesi, Indonesia Am. J. Sustain. Agric. 2016. 10(3) 1-6.

[7] Chattopadhyay A. A study on status of higher education of women and economic empowerment in India Res. J. Soc. Sci. 2018. 9 (7), 41-49.

[8] Sirajuddin S N, Asnawi A, Syawal S and Jamal M. Response of cattle breeders to ricestraw silage in Soppeng Regency, South Sulawesi Province Am. J. Sustain. Agric. 2016. 10 33-7.

[9] Desmita. Psikologi Perkembangan. Bandung. PT Remaja Rosdah Karya; 2008.

[10] Ahmad Z. Present Status of Women Empowerment in Kashmir with special reference to Srinagar District of Kashmir Valley Res. J. Soc. Sci. 2019. 10 (5), 112-118.

[11] Saleha Q, Hartoyo H and Hastuti D. Manajemen Sumberdaya Keluarga: Suatu Analisis Gender dalam Kehidupan Keluarga Nelayan di Pesisir Bontang Kuala, Kalimantan Timur J. Ilmu Kel. Konsum. 2008. 1 118-30. 